\title{
A Spatial Regression Approach to FDI in Vietnam: Province-level Evidence*
}

\author{
BULENT ESIYOK \\ Faculty of Economics and Administrative Sciences \\ Baskent University, Ankara, Turkey \\ MEHMET UGUR \\ Business School, University of Greenwich, UK
}

\begin{abstract}
Foreign direct investment flows into Vietnam have increased significantly in recent years and are distributed unequally between provinces. This article aims to investigate the locational determinants of foreign direct investment in 62 Vietnamese provinces and whether spatial dependence is a significant factor that both researchers and policy-makers should take into account. We report that province-specific per-capita income, secondary education enrolment, labor costs, openness to trade, and domestic investment affect foreign direct investment directly within the province itself and have indirect effects on foreign direct investment in neighboring provinces. The direct and indirect effects coexist with spill-over effects and spatial dependence between provinces. Our findings indicate that foreign direct investment in Vietnam reflects a combination of complex vertical and export platform motivations on the part of foreign investors; and an agglomeration dynamic that may perpetuate the existing regional disparities in the distribution of foreign direct investment capital between provinces.
\end{abstract}

Key words: Foreign direct investment, spatial dependence, agglomeration, Vietnam.

JEL classification numbers: C31, F23, R12.

\footnotetext{
* Accepted for publication in The Singapore Economic Review. DOI: 10.1142/S0217590815501155
} 


\section{A Spatial Regression Approach to FDI in Vietnam: Province-level Evidence}

\section{Introduction}

Locational determinants of foreign direct investment (FDI) have been investigated extensively, but empirical work on determinants of FDI in sub-national units is limited to few studies that concentrate mainly on China. In addition, most of the empirical work overlooks spatial interdependence between host markets - even though foreign investors' location decisions involve a choice between competing host units that are related to each other through physical distance among other factors. This is particularly the case when one investigates the distribution of FDI between sub-national units that are subject to a common set of macroeconomic and trade policies. Therefore, investigating the patterns of interdependence and whether the latter is conducive to agglomeration or competition effects are important for correct inference and evidence-based policy and practice.

As Blonigen et al. (2007) indicate, spatial econometrics provides useful techniques that investigate spatial interdependence between countries or sub-national regions. In this article, we use a spatial lag model that allows for: (i) estimating the degree of spatial dependence between FDI capital registered in Vietnamese provinces; and (ii) distinguishing between the direct, indirect and feedback effects that province-specific factors such as per-capita GDP, labor cost, openness to trade and education, governance quality, etc. have on FDI within the province itself and its neighbors.

Application of spatial regression analysis to FDI in Vietnamese provinces can enhance the evidence base and provide better support for evidence-based policy for several reasons. First, 
during the period under investigation (2006-2009), Vietnamese provinces have attracted high levels of FDI flows that have enabled Vietnam to register the second-highest FDI/GDP ratio after Singapore. Furthermore, provincial authorities in Vietnam have been competing to attract foreign investors, using fiscal incentives and disseminating province-level data on governance quality, education, labor training facilities, infrastructure, etc. These developments raise policyrelated questions as to whether FDI in Vietnamese provinces have been subject to competition or agglomeration dynamics and with what implications for regional convergence/divergence.

Spatial dependence analysis is also called for because it allows for addressing theoretical/empirical questions concerning the type of foreign investors (i.e., whether the latter consist of horizontal, vertical or complex vertical multinational enterprises) and the extent to which FDI is geared to supply the domestic or export markets. Finally, spatial regression is also necessary to address inference problems that arise when spatial dependence exists in the data generating process. In the presence of spatial dependence, ordinary least-squares (OLS) estimates are biased because the assumption of cross-sectional independence is violated and the exclusion of the spatial dependence causes model misspecification bias.

To address these issues, we begin with a review of the relevant literature in section 2 , where we draw attention to the relative absence of spatial analysis in empirical studies on the Pacific region in general and Vietnam in particular. This is followed by contextual information on FDI in Vietnam in section 3, which summarizes the distribution of FDI between provinces and the share of 'foreign-invested sector' in total export earnings over the last decade. Section 4 describes the data and introduces the spatial regression methodology. In section 5, we present the empirical findings, which consist of a set of estimates for spatial dependence and direct and indirect effects, based on different specifications of the number of neighboring provinces and/or 
the distance between provinces. Section 6 summarizes the main findings and distils some policy implications.

\section{Literature review}

Reliance on a two-country (or bilateral) framework that consists of one home and one host country is a potential weakness in the theoretical and empirical work on locational determinants of FDI (Blonigen et al. 2007). There are two reasons as to why this may be the case. First, FDI decisions by multinational enterprises (MNEs) may be motivated by horizontal, vertical or complex-vertical specialization motives that, in turn, induce MNEs to consider the characteristics of both host- and third-countries. Baltagi, Egger, and Pfaffermayr (2007) and Blonigen et al. (2007) provide a useful typology of MNEs' specialization motives and how the latter can be ascertained from the sign of the spatial dependence between a host country/region and third countries. If MNEs are motivated by horizontal investment considerations aimed at circumventing trade restrictions or high transportation costs, spatial dependence should not be observed because horizontal FDI decisions depend on the difference between the benefits of investment location's proximity to the destination market and the cost of installing a new plant in that location. In the case of pure vertical FDI, however, MNEs evaluate all potential destination countries/regions to find the lowest-cost provider of the operations it wishes to relocate. Therefore, vertical FDI in one location usually occurs at the expense of other locations in its neighborhood. This type of spatial interdependence is captured by a negative coefficient on the spatial dependence variable.

However, pure horizontal or vertical motives are rarely the norm, with majority of the FDI flows reflecting complex vertical specialization considerations. In such cases, we expect a positive spatial dependence between host countries/regions and third countries/regions. This is 
because complex vertical specialization involves segmentation of the production activities, each of which may be located in a separate geographic unit. In this case, FDI in one region may be correlated positively with investment in neighboring regions either because of existing suppliers in the latter or due to agglomeration effects that may be caused by 'natural resources' such as mines or infrastructure facilities such as ports (Blonigen et al. 2007).

The earliest attempt at estimating the determinants of FDI by taking account of spatial interdependence is the study of Head, Ries, and Swenson (1995), which examines the role of agglomeration effects in determining the location of Japanese FDI in the US. They use a conditional-logit model and report that agglomeration effects between bordering states are significant. Head and Mayer (2004), on the other hand, examine the distribution of Japanese FDI in the European Union, taking account of distance-weighted or trade-frictions-weighted GDP in adjacent regions. They report that more developed regions attract higher levels of FDI and that this effect is robust to inclusion of agglomeration measures as in Head, Ries, and Swenson (1995). Although innovative, these studies utilize discrete choice models and as such they do not use the existing data on FDI levels efficiently (Blonigen et al. 2007,p.1305).

In between, Coughlin and Segev (2000) use a spatial error model to estimate the determinants of US FDI across Chinese provinces. They conclude that a shock to FDI in one province has positive effects on FDI in nearby provinces. Furthermore, they report that market size, labour productivity, coastal location, wages, and illiteracy rates are statistically significant, while transportation cost is not a significant determinant of FDI across Chinese provinces. Coughlin and Segev (2000) represent the first departure from the discrete choice models developed by Head, Ries, and Swenson (1995) and Head and Mayer (2004). It also motivated two seminal 
contributions by Baltagi, Egger, and Pfaffermayr (2007) and Blonigen et al. (2007), both of whom examine the impact of spatial dependence on outbound US FDI.

Baltagi, Egger, and Pfaffermayr (2007) develop a model of FDI activity that allows for a variety of MNE motivations and spatial interactions. They report significant evidence of spatial interactions, but they cannot conclude whether export-platform or complex vertical FDI motivation is the dominant one. On the other hand, Blonigen et al. (2007) find that spatial interdependence has a significant effect on the distribution of FDI between neighboring countries and that the estimated parameters for the traditional determinants of FDI (i.e., for the host-country characteristics) are robust to inclusion of spatial interdependence terms. Nevertheless, Blonigen et al. (2007) also report that the existence of spatial interactions does not necessarily allow for robust conclusions about export-platform or complex-vertical motivations for FDI. This is because the estimated spatial interdependence may be sensitive to sample selection.

Mainly due to data constraints, the volume of work on sub-national distribution of FDI in developing countries is small and the number of studies utilizing spatial analysis is even smaller. For example Na and Lightfoot (2006), and Du, Lu, and Tao (2008), Cole, Elliott, and Zhang (2009) investigate the locational determinants of FDI across Chinese provinces; but without taking account of spatial dependence between regions. Using a panel of 30 provinces and 6 years from 1998-2003, Cole, Elliott, and Zhang (2009) report that provincial GDP per capita, government efficiency, anti-corruption effort, good road transportation networks, and surplus of unskilled labor are significant determinants of FDI across provinces. On the other hand, $\mathrm{Na}$ and Lightfoot (2006) use cross-section data for 30 regions in 2002 and conclude that market size, labor quality, labor costs, and the level of infrastructure are important determinants 
of FDI. Du, Lu, and Tao (2008) confirm the significance of economic institutions, wages and infrastructure; while they further add special economic zones, coastal cities to their analysis of locational determinants of US multinationals in China. Finally, Karim and Fleming (2012) find that FDI inflows in manufacturing sector across 13 states and 1 federal territory in Malaysia are responsive to market demand, labor productivity, and socio-economic development.

In the case of Vietnam, Pham (2002) uses averaged data over the period 1988-1998 and provides OLS estimates of the FDI determinants in 53 provinces. The author finds that percapita income, labor quality and phone lines per capita are related to FDI flows. Another empirical work is Malesky (2007), who uses cross-section data with different measures of FDI, including new FDI projects licensed, implemented FDI as a proportion of registered FDI, and additional capital for existing projects. The findings indicate that FDI is not related to GDP per capita, labor quality, and tax incentives; but different measures of FDI are found to be related positively to different measures of institutional/governance quality. Using the provincial competiveness index (PCI) and its constituent components, Malesky (2007) reports that the investment attraction capacity of the provinces is positively related to the transparency of regulatory information and private sector development services they provide. However, the level of implemented FDI is mostly influenced by the security of property rights.

Using a panel data for 60 provinces over the period 2000-2005, Vu, Le, and Vo (2007) investigate the relationship between FDI and tax incentives offered by provincial governments independently of the national government. The effect of tax incentives on FDI is rejected by their study but investment climate measured by PCI, infrastructure, proximity to major markets, and education are found statistically significant. Furthermore, while per-capita GDP is found to have no effect on implemented FDI, the effect of wage level is reported as positive. Finally, 
Nguyen (2006) and Pham (2008) report that per-capita income, education, domestic investment, exports, skills, and labor cost are related to province-level FDI.

However, none of the studies above account for spatial dependence between Vietnamese provinces. For other countries, we have already noted Coughlin and Segev (2000), who use a spatial error model to analyze the determinants of FDI in 29 Chinese provinces. The authors conclude that an FDI shock in one province has positive effects on FDI in nearby provinces. With respect to Russia, Ledyaeva (2009) finds weak evidence of competition between provinces for FDI and reports that that market size, the presence of big cities and sea ports, oil and gas resources, distance to the European market, political and legislation risks and FDI in neighboring regions are important determinants of FDI in Russia. In the context of the Spanish regions, Villarde and Maza (2011) report absence of spatial dependence in the dependent variable (FDI) but presence of significant effects from spatially-lagged independent variables. Finally, Gamboa (2013) shows complementarity between FDI in a host state and neighboring states in Mexico. Market size, wages and education are among other variables that explain variation in FDI between Mexican states. Table 1 below presents empirical findings on FDI with respect to spatial dependence between sub-national regions.

\section{Table 1 to go here}

The review above indicates that the number of FDI studies that utilize spatial analysis at the country, regional or provincial levels is small. Furthermore, a spatial analysis of the FDI in Vietnamese regions is yet to emerge. Therefore, we aim to contribute to the emerging literature in three areas. First, we provide a range of empirical estimates for conventional FDI determinants and spatial dependence, using spatial regression models with different specifications for weight matrices based on different numbers of neighboring provinces and different cut-off values for distance between provinces. In doing this, we follow LeSage and 
Pace (2009) and Elhorst et al. (2010a) to test for the weight matrix specification that best fits the data. Secondly, we provide estimates of not only direct but also indirect effects of the spatial interdependence on FDI. The direct effect refers to the extent to which FDI in a host province is affected by the province-specific explanatory variables. The indirect effect, on the other hand, measures the extent to which a given change in explanatory variables for the host province affects FDI in other provinces. Third, we evaluate the sign and magnitude of the spatial interdependence coefficient to establish whether agglomeration or competition effects dominate in the distribution of FDI between Vietnamese provinces; and whether FDI capital in Vietnamese provinces is motivated by complex vertical integration and export platform motivations of the MNEs.

\section{FDI in Vietnamese provinces}

Liberalization of FDI policies in Vietnam dates back to the first FDI Law, which was introduced in 1987 and amended several times in 1992, 1996 and 2000 with a view to provide a better investment climate for foreign investors. These policies to promote FDI succeeded in attracting Japanese FDI inflows, albeit at low levels (Urata and Kawai, 2000). In a further effort to liberalize FDI policies, the Unified Law of Investment replacing previous laws and regulations was accepted in 2006. Equal treatment of foreign and domestic investors was the major innovation in the Unified Law, which was introduced to comply with the requirements of the World Trade Organization (WTO) membership. Liberalization of FDI policies coupled with WTO membership in 2007 boosted FDI inflows in Vietnam.

Table 2 below presents the sectoral composition of registered FDI in 2009. According to Table 2, manufacturing is the most attractive sector for foreign investors in Vietnam with a share of $51.05 \%$ of registered FDI. Second to manufacturing is the real estate activities sector, receiving nearly a quarter of registered FDI. Compared with manufacturing and real estate activities, the 
other sectors attract relatively less FDI. Dominance of the manufacturing sector is also felt in exports of Vietnam. Manufactured products generated nearly $60 \%$ of total export earnings in 2009. ${ }^{1}$ Relatively high share of manufacturing in both FDI and export earnings imply that foreign investors might be motivated to locate production in Vietnam in order to ship goods either to country of origin or third countries from Vietnam.

\section{Table 2 to go here}

FDI inflows into Vietnamese provinces are concentrated mainly in North-Central, CentralCoastal, South-Eastern and the Red River regions. As Table 3 indicates, ten provinces from these regions hold $85 \%$ of cumulative FDI in 2009. Of these ten provinces, Ho Chi Minh City (HCMC), Ba Ria-Vung Tau (BRVT), Dong Nai and Binh Duong of South-Eastern regions stand out with 51\% share in total FDI. The top three provinces in terms of FDI inflows in Table 3 are also the richest provinces in Vietnam according to per capita GDP figures for 2009.

\section{Table 3 to go here}

The map of Vietnam below provides an overview of cumulative FDI inflows in 2009. White areas indicate the provinces with ten lowest FDI inflows, while brown areas show the provinces with highest FDI inflows. Provinces with low FDI inflows are located together. For instance, Ha Giang, Cao Bang and Bac Kan in the North and Dak Nong, Dak Lak and Gia Lai in the South-West are neighbors. By the same token, there is a correlation in space among provinces with high FDI inflows. Four provinces with highest FDI inflows in the South-East are clustered and they are surrounded by provinces with high FDI inflows as well.

\footnotetext{
${ }^{1}$ The share of earnings of manufactured goods calculation is based on data by Exports of goods by standard international trade classification (SITC) provided by the General Statistics Office in Vietnam.
} 


\section{Figure 1 to go here}

Finally, the existing evidence indicates that FDI investment decisions are highly likely to be informed by 'export platform' considerations in addition to horizontal, vertical or complex vertical specialization considerations of the foreign investors. The share of the 'foreign-invested sector' in export earnings has been historically high - at about 30\% until the end of the 1990s. The share has increased to 54\% over the decade from 2000-2010 (General Statistics Office of Vietnam). This high level of export orientation requires careful examination of the spatial dependence between Vietnamese provinces. The latter are not 'alternative export markets' for foreign investors. Rather, they are just parts of a single jurisdiction and as such they can be considered only as alternative locations or platforms for MNE exports to the rest of the world. Given this property and the high level of export-orientation, the distribution of FDI between Vietnamese regions may be subject to agglomeration rather than competition effects; and the province-specific factors may have direct and indirect effects with similar rather than opposite signs.

In section 4 below, we model spatial interaction between provinces using distance-weighted or neighboring-province-weighted matrices, with different cut-off values for distance and different numbers of neighboring provinces. We report estimation results for spatial interaction with one nearest neighbor, three nearest neighbors, $186 \mathrm{~km}$ and $350 \mathrm{~km}$. The cut-off distance of $186 \mathrm{~km}$ ensures that a province has at least 3 nearest neighbor (with an average of 12 neighbors), whereas the cut-off distance of $350 \mathrm{~km}$ ensures that a province has at least 7 nearest neighbors (with an average of 19 neighbors).

\section{Methodology and data}


The existing literature tends to focus on a range of locational factors that affect FDI inflows at the national or sub-national levels. Our choice of FDI determinants is informed by the literature reviewed above and province-level data availability for Vietnamese provinces. Our dataset covers 62 out of 63 provinces from six regions of Vietnam for the period 2006-2009. ${ }^{2}$ This leads to a balanced panel dataset of 248 observations in total with respect to data on 62 provinces over a four year period.

As dependent variable, we use the natural logarithm of the per-capita registered FDI capital (lnFDI) in provinces, measured in Vietnamese Dong (VND). Original data for FDI were in current US\$, which we converted to (VND) using exchange rate (market rate). Our FDI measure is scaled by the population of each province with a view to reduce the risk of heteroscedasticity related to scale (Baum 2006).

In line with the empirical literature on locational determinants of FDI (Segev 2000; Pham 2002; Malesky 2007; Cole, Elliott, and Zhang 2008; Pham 2008), we use the natural logarithm of percapita GDP ( $\ln P C G D P)$ in each province as a measure of market potential. We expect higher levels of per-capita GDP to lead to higher levels of registered FDI. The natural logarithm of provincial domestic investment scaled by provincial population $(\ln D I)$ is used to check whether domestic investment function as a substitute or complement to FDI. Openness to international trade $(\ln O P)$ is defined as the natural logarithm of the percentage share of provincial exports and imports in provincial GDP. Original values of exports and imports in current US\$ were first converted to VND then divided by GDP. We expect openness to have a positive effect on provincial registered FDI capital because relatively more open provinces are more likely to offer the right mix of infrastructure and skills required by MNEs. Labor costs are an important

\footnotetext{
${ }^{2}$ We exclude one province (Bac Lieu) for which data is incomplete. See Appendix A1 for the list of provinces covered by our sample.
} 
component of production costs, for which we control by using a real wage proxy. Labor cost $(\ln L C)$ is the natural logarithm of compensation per employee per month; and it is expected to have a negative effect on registered FDI capital in each province.

As far as human capital is concerned, we use the natural logarithm of the lower secondary school enrolment per 1000 inhabitants $(\ln L S)$ in each province. We expect FDI within each province to be related positively to lower secondary-school enrolment between the ages of 1115 years. This is because lower-secondary education is a good indicator of literacy and a precursor of the vocational technical education that would follow. Finally, we include the Provincial Competitive Index $(P C I)$ to measure the impact of governance quality on FDI. ${ }^{3}$ Higher values of $P C I$ indicate better governance, which we assume to have a positive impact on registered FDI. ${ }^{4}$ All monetary values were deflated to 2005 VND.

Data for FDI, GDP per capita, domestic investment, exports, imports and lower school secondary enrolment are provided by General Statistics Office of Vietnam (GSO). We collected labor cost data from the principle indicators of enterprises by regions and provinces published by GSO. We retrieved PCI data from its online source. Data sources and summary statistics for all the variables in level are provided in Table A3 and A4 in the Appendices, respectively.

The empirical model is specified below, with subscripts $i(1, \ldots, 62)$ and $t(1, \ldots, 4)$ denoting province and time, respectively.

$$
\begin{gathered}
\ln F D I_{i t}=\beta_{1} \ln P C G D P_{i t}+\beta_{2} \ln D I_{i t}+\beta_{3} \ln L C_{i t}+\beta_{4} \ln O P_{i t}+\beta_{5} \ln L S_{i t}+\beta_{6} P C I_{i t} \\
+\varepsilon_{i t}
\end{gathered}
$$

\footnotetext{
${ }^{3}$ PCI measures the perceived quality of economic governance institutions and business environment at the province level and consists of nine sub-indexes: entry costs; land access and security of tenure; transparency and access to information; time costs of business start-ups; proactivity or local administration; informal charges; quality of business support services; labor training services; and legal institutions.

${ }^{4}$ For robustness check, we used enrolment in upper secondary school as a proxy for human capital and corruption as a proxy for governance quality. The results remain same and can be provided upon request.
} 
Equation (1) overlooks the potential for spatial dependence either in the dependent variable $(\operatorname{lnFDI})$ or through the error term $(\varepsilon)$. To check whether spatial dependence exists, we use the Lagrange Multiplier (LM) test proposed by Anselin (1988). The null hypothesis in the LM tests posits the absence of spatial dependence, the rejection of which indicates the existence of spatial dependence that may be due to 'spatially-lagged' dependent variable or spatially-autocorrelated errors. Hence correct specification of the model in (1) must take account of both types of spatial dependence - as indicated in equations (2) and (3) below.

$$
\begin{gathered}
\quad \begin{array}{c}
\ln F D I_{i t}=\alpha+ \\
+\beta_{1} \ln P C G D P_{i t}+\beta_{2} \ln D I_{i t}+\beta_{3} \ln L C_{i t}+\beta_{4} \ln O P_{i t}+\beta_{5} \ln L S_{i t} \\
+\beta_{6} P C I_{i t}+\rho W \ln F D I_{j t}+\psi_{i t}
\end{array} \\
\begin{array}{c}
\psi_{i t}=\lambda W \psi_{j t}+\varepsilon_{i t} \\
-1 \leq \rho \leq 1 \quad \text { and } \quad-1 \leq \lambda \leq 1
\end{array}
\end{gathered}
$$

Two main differences are evident here. First, the model is augmented with a new term that captures the spatial dependence in the dependent variable $\left(\rho W \ln F D I_{j t}\right)$. Here, $\rho$ is the 'spatial lag' and $W$ is a weight matrix based on distance between provinces. Spatial dependence in the dependent variable is known as the spatial lag problem and is captured by the spatial autoregressive coefficient $\rho$. The latter measures the extent to which FDI in neighboring spatial units has an exogenous effect on FDI in a host unit, after controlling for the effect of other exogenous variables. Therefore, ignoring this type of spatial dependence is tantamount to model misspecification, which leads to biased estimates and invalid statistical inference.

Secondly, the error term $\left(\psi_{i t}\right)$, as defined in (3), consists of two terms: the idiosyncratic error term $\left(\varepsilon_{i t}\right)$ and a spatially-weighted autoregressive component $\left(\lambda W \psi_{j t}\right)$. This specification captures the spatial dependence between the error terms, which is usually known as the 'spatial 
error' problem. This problem arises when a shock to FDI in neighboring provinces affect the level of FDI in a host province through the error term. In such cases, OLS estimates are unbiased but the inference based on OLS estimation is invalid because the standard errors of the estimates do not take account of spatial autocorrelation.

As indicated above, the LM tests allow for establishing if one or both types of spatial dependence exist in the data and hence whether OLS estimation should be rejected in favor of estimators that take account of spatial interdependence. The LM test for spatial lag tests the hypothesis whether $\rho=0$ in Equation (2) and LM test for spatial error tests if $\lambda=0$ in Equation (3). Note that the spatial interaction coefficients ( $\rho$ and $\lambda)$ must satisfy the condition in (4) - i.e., they must range between -1 and 1 .

Spatial interaction is modeled as a weight matrix $(W)$ based on distance $(d)$ between Vietnamese provinces. The level of spatial dependence is modeled to diminish at a quadratic rate as distance increases. Hence, heavier weights are attached to nearer neighbors than distant ones. Given the poor transportation infrastructure and s-shape of Vietnam, it is plausible to think that interaction between nearer neighbors would be much stronger than distant ones. The advantage of using physical distance is due to its exogeneity with respect to FDI (Anselin and Bera 1998). Empirical studies use different specifications for distances, including the nearest neighbor, contiguous provinces, distance-based matrices, and distance-based matrices with a critical cutoff value. In the absence of clear guidance for the choice of cut-off distance, empirical studies make use of the log-likelihood and R-squared values to compare estimation results based on different weight matrices (Abreu, de Groot, and Florax 2004; Seldadyo, Elhorst, and de Haan 2010). In this study, we use four different specifications for the distance-based weight matrix: the nearest neighbor (W1); the nearest three neighbors (W3), all neighbors within a radius of $186 \mathrm{~km}$ from the capital of the host province (W186) which ensures that we have at least 3 neighbors for the host province; all neighbors within a radius of $350 \mathrm{~km}$ from the capital of the 
host province (W350), which ensures that we have at least 7 neighbors for the host province. We take capital cities of provinces as reference points in calculating distance between provinces. As provinces get larger, distances to neighbors increase. In addition, provinces in the middle of the country such as Quang Binh and Ha Tinh are more distant from their neighbors than provinces in the north and south are. At this point, choice of a cut-off distance value becomes critical. Because a small cut-off value considerably reduces the number of neighbors with which large provinces and provinces located in the middle of the country interact. Bearing this in mind, we choose a cut-of value of $186 \mathrm{~km}$ in order to allow each province to interact at least with three neighbors. By the same token, we increase cut-off value from $186 \mathrm{~km}$ to $350 \mathrm{~km}$ to allow each province to interact at least with 7 neighbors. We use these different specifications in order to verify if spatial dependence vary with distance and whether there is a critical distance beyond which indirect and feedback effects due to spatial dependence cease to be important.

Quite often, the spatial lag model is preferred to the spatial error model. This is because the former allows for obtaining a rich set of estimates for the effects of a given explanatory variable - including direct, indirect and feedback effects. In addition, the spatial lag model also allows for establishing whether spatial dependence is reflected as agglomeration or competition effects in the distribution of FDI between spatial units (Blonigen et al. 2007). However, the choice between the two must be based on the Lagrange Multiplier (LM) test (Anselin 1988) - as indicated above.

If the test indicates estimation with spatial lag, LeSage and Pace (2009) propose a calculation method that decomposes the total effect into direct and indirect effects. The direct effect refers to change in the province-specific FDI capital in province $i$ caused by a one-unit change in the explanatory variable(s) for that province. The indirect effect, which is also known as spatial spill-over effect, measures the change in province-specific FDI capital in province $j$ (where $j \neq$ $i$ ) caused by unit change in the explanatory variables of province $i$. Finally, the feedback effect 
is calculated as the difference between the direct effect and the point estimate (Seldadyo,

Elhorst, and de Haan 2010); where the point estimate is the estimate of $\beta$ in model (2).

\section{Empirical results}

Table 4 below presents our findings on the determinants of registered FDI capital in Vietnamese provinces from 2006 -2009. Panel (1) reports the OLS estimation results without spatiallylagged dependent variable. Panel (2) presents the results of the maximum likelihood (ML) estimations, which include the spatially-lagged dependent variable (WlnFDI) as explanatory variable. The ML estimation results and the Lagrange Multiplier (LM) tests in Panel (2) are based on different specifications for neighboring provinces. The specifications for weight matrix include one nearest neighbor (W1), three nearest neighbors (W3), a distance cut-off value of $186 \mathrm{~km}$ (W186) that ensures the weight matrix includes at least three neighbors; and a distance cut-off value of $350 \mathrm{~km}(\mathrm{~W} 350){ }^{5}$

At the bottom of Table 4, we report the results of the LM tests for spatial dependence and for deciding whether the latter should be modeled as spatial error or spatial lag. In all specifications of the distance-based weight matrix, the LM tests failed to reject the null hypothesis of no spatial dependence in the error term. In contrast, the LM tests for absence of spatial dependence in the dependent variable are rejected under three specifications of the weight matrix: W1, W3 and W186. The null hypothesis of no spatial lag cannot be rejected when the weight matrix is based on a distance cut off of $350 \mathrm{~km}$. In such cases, Anselin et al. (1996) proposes a robust LM test to establish whether spatial lag estimation is still preferable to OLS estimation when the LM test is inconclusive. The robust LM test rejects the hypothesis of no spatial lag when

\footnotetext{
${ }^{5}$ We have also used two other matrices based on two nearest neighbors and distance cut off at $500 \mathrm{~km}$. The results remain unchanged and can be supplied upon request.
} 
the weight matrix is specified at a distance cut-off of $350 \mathrm{~km}$ too. Hence, all results reported in Panel (2) of Table 4 are based on ML estimation of the spatial lag model specified in equation (2) above.

\section{Table 4 to go here}

The coefficient of the spatial lag (i.e., the coefficient of $W \ln F D I$ ) is positive and significant under all specifications of the weight matrix. In fact, the level of spatial dependence tends to increase from 0.116 to 0.183 as the distance between province $i$ and its neighbors or the number of neighboring provinces increases. Technically, this finding indicates that the OLS estimates in panel 1 would be biased due to omission of the spatial lag term from the model. The positive coefficient also confirms the positive spatial autocorrelation in $\ln F D I$ results obtained from the Moran s I test, which are reported in Table A2 of the Appendix for each year and each weight matrix specification. ${ }^{6}$

More importantly, however, our findings point out the existence of an agglomeration dynamic in the distribution of FDI capital across Vietnamese provinces. The presence of FDI activities in neighboring provinces appears to have a positive effect on FDI in a given province and this effect is in addition to the partial effects of the locational factors specific to the province itself. In fact, this spatial dependence explains why cumulative FDI is clustered in the North, the Middle and South of the country, with each cluster being centered around a core of provinces with the highest levels of FDI concentration (see map in Figure 1 above). The spatial

\footnotetext{
${ }^{6}$ Moran's I statistic tests whether provinces, which are located closer together are more likely to have similar registered FDI levels than those which are further apart. The null hypothesis for this tests states that there is zero spatial autocorrelation in the variable $\ln F D I$.
} 
dependence and the agglomeration effects it depicts are partly due to geographical characteristics such as natural ports. Indeed, the provinces with the highest levels of concentration are located near major ports, which include Cam Pha. Quang Ninh and Vat Cach in the North; Da Nang in the Middle and Saigon, Nha Trang and Sa Dec in the South.

The spatial lag estimation allows not only for detecting the existence or absence of agglomeration effects as indicated above but also for establishing the extent to which spatial dependence is reinforced through the locational characteristics of each province. In other words, it allows for opening up the 'black box' through which the agglomeration effects are unfolding. The agglomeration effects may be driven by physical geography factors such as ports or infrastructure facilities such as airports or highways. However, they may also be due to economic/demographic factors that foreign investors also take into account.

The results in Table 4 enable us to establish the extent to which spatial dependence is reinforced or ameliorated through economic/demographic factors. This can be established by examining the indirect-effect estimates reported in Table $4 .{ }^{7}$ Our results indicate that the province-specific per-capita GDP, domestic investment, openness to trade and lower-secondary enrolment ratio all have positive indirect effects on FDI capital in neighboring provinces. Province-specific labor costs, on the other hand, have negative effects. The indirect effects have the same sign as direct effects. Furthermore, they are significant when the weight matrix is based on the nearest one neighbor or nearest 3 neighbors; but they become insignificant as the distance increases. Hence, we can conclude that the province-specific economic/demographic factors affect the level of FDI in the province itself and its immediate neighbors in the same direction.

\footnotetext{
${ }^{7}$ The estimation of direct and indirect effect is based on procedures proposed by LeSage and Pace (2009).
} 
This finding indicates that stronger market potential, openness to trade or higher levels of secondary education in one province attract FDI not only into the province itself but also into its neighboring provinces. This is because FDI decisions are likely to have been influenced not only by the economic/demographic potential of a given province itself but also by that of its immediate neighbors - which can serve either as markets for finished products/services or as additional source of labor or skills. Such market complementarities or externalities are more likely to be the case when the unit of analysis is a sub-national province (as it is the case here) rather than a different jurisdiction because the mobility of goods and services between subnational units is usually higher than the level of mobility between different jurisdictions.

Our findings also enable us to derive some conclusions about MNE motivations for FDI in Vietnam. As indicated in sections 2 and 3 above, MNE engagement in FDI may be due to complex vertical integration and/or export platform motives. According to the typology identified by Baltagi, Egger, and Pfaffermayr (2007) and Blonigen et al. (2007), FDI is driven by complex vertical integration motives when the sign of the spatial lag is positive and significant. Also, FDI is driven by export platform motives when the sign of the indirect effects is positive and significant. Our findings indicate that FDI in Vietnam is driven by complex vertical integration and export platform motives. In both cases, the existence of FDI activity in one province/region is not at the expense of neighboring regions/provinces because foreign investors aim to supply not only the local but also the international market. This is compatible with the descriptive evidence on the composition of Vietnamese exports - which indicates more than $50 \%$ of Vietnam's total export earnings have been generated by the foreign-invested sectors since 2000 .

Furthermore, our findings enable us to compare and contrast different types of estimates within a unified framework. For example, when compared to ML estimates, OLS estimates tend to over-estimate the effects of provincial per-capita GDP $(\ln P C G D P)$, openness to trade $(\ln O P)$ 
and lower-secondary school pupils $(\ln L S)$; but they underestimate the effects of domestic investment $(\ln D I)$ and labor cost $(\ln L C)$. The over- or under-estimation is due to model misspecification bias caused by absence of spatial lag variable in the OLS specification. Although point estimates obtained from the ML estimation are reliable for inference, they may also under- or over-estimate the true effect of each explanatory variable. As noted by Elhorst (2010a), the true marginal effects (i.e., the partial derivatives of model 2) are the direct-effect estimates. ${ }^{8}$ Hence, inference about the effects of locational factors should be based on directeffect rather than point estimates; and the difference between the point and direct-effect estimates is equal to the feedback effect (Seldadyo, Elhorst, and de Haan 2010). The latter occurs as a result of second- and higher-order spill-over effects from neighboring provinces following the initial change in the province-specific determinant of FDI.

Having summarized the range of estimates that can be obtained from spatial regression analysis, we can now summarize the findings related to true marginal effects - i.e., to direct-effect and indirect-effect estimates. The direct-effect estimates indicate that higher levels of provincespecific per-capita GDP $(\ln P C G D P)$, per-capita domestic investment $(\ln D I)$, trade openness $(\ln O P)$, perceived governance quality $(\mathrm{PCI})$ and lower-secondary enrolment $(\ln L S)$ lead to higher levels of registered FDI capital $(\operatorname{lnFDI})$. The estimate is negative only in the case of labor costs. These findings are in line with OLS estimates reported by $\mathrm{Na}$ and Lightfoot (2006) and Cole, Elliott, and Zhang (2009) with respect to FDI across Chinese regions; and with those reported by Pham (2002, 2008) and Nguyen (2006), Vu, Le, and Vo (2007), and Malesky (2007) with respect to Vietnamese provinces.

\footnotetext{
${ }^{8}$ For calculating direct and indirect effect estimates, we used the 'panel_effects_sar' function in Matlab, which is developed by Le Sage and Pace and adapted for the spatial panel models by Elhorst. See, http://www.regroningen.nl/elhorst/software/panel_effects_sar.m.
} 
With respect to market size, our findings are similar to those of Ledyeva (2009), Coughlin and Segev (2000) and Gamboa (2013), who investigate determinants of FDI in Russian regions, Chinese provinces and Mexican states, respectively. In addition, labour cost is reported to have a negative effect on FDI in Chinese provinces and Mexican states, as we have found in the case of Vietnamese provinces. As for the nature of spatial dependence, we find a positive spatial dependence in FDI between provinces in Vietnam in contrast to Russian regions. The magnitude of positive spatial dependence we present here is smaller than the one for Mexican states reported by Gamboa (2013). These findings suggest that the nature and strength of spatial dependence in FDI, if exists, may vary across countries at subnational regions, reflecting different motives for FDI and degrees of spatial dependence between geographic units.

Nevertheless, our findings enhance the evidence in three directions. First, we demonstrate that estimates reported by the existing literature may have the correct sign but they may also be subject to model misspecification bias, which is due to exclusion of spatial dependence from estimated models. Secondly, we demonstrate that unit-specific locational factors have both direct effects on FDI within the province itself and indirect effects on FDI in neighboring provinces. The indirect effects are smaller in magnitude but have the same sign as the direct effects.

The third contribution relates to uncovering an agglomeration dynamic in the distribution of FDI across Vietnamese provinces. Our findings indicate that the agglomeration effects unfold through spatial dependence between provinces and via indirect effects of the locational economic and demographic factors. Given that the direct and indirect effects have the same sign, agglomeration effects through both channels reinforce each other within provincial clusters that consist of two or four provinces - i.e., when the weight matrix is based on one nearest and three nearest neighbors. When the number of neighboring regions exceeds four, the agglomeration effect captured by the spatial dependence continues to exist, but it is not 
reinforced by market complementarities captured by the indirect effects of locational characteristics such as market size, openness to trade, education, wages and economic governance quality.

\section{Conclusions}

In this article, we have investigated the locational factors that affect FDI inflows into subnational units in Vietnam, taking into account both economic/institutional factors and the interactions of the latter with geography. Using a dataset on registered FDI capital in 62 Vietnamese provinces from 2006-2009 and drawing on recent developments in spatial regression methodology, we have discovered a number of empirical patterns that enhance the existing evidence base and may inform policy and practice.

First, we have demonstrated that OLS estimates for the effects of locational determinants of FDI inflows would be biased if the latter are subject to spatial dependence, measured as geographical proximity of the host provinces. The bias is equal to the difference between the point estimates from OLS estimation and the direct-effect estimates from the maximum likelihood estimation with spatial dependence. The difference is about $10 \%$ and reflects either an upward bias (as it is the case for the effects of per-capita GDP and education on FDI flows) or a downward bias as it is the case for the effect of domestic investment on FDI flows. The implication for future research is that it is necessary to test for the presence of spatial dependence in FDI flows and the case for such tests is stronger when geographical units correspond to provinces or regions within the same country.

Second, the signs and significance of the bias-corrected direct-effect estimates we have found are in line with existing findings with or without control for spatial dependence. Hence, we have confidence in the inference quality of our findings that take account of spatial dependence. Our bias-corrected findings indicate that province-level per-capita GDP, domestic investment, 
openness to trade, governance quality and education have positive effects on FDI inflows into provinces; whereas labor costs have a negative effect. These bias-corrected estimates remain robust to different specifications of geographical proximity, ranging from three neighbors to $350 \mathrm{~km}$ that envelope at least 7 neighboring provinces.

Third, we have added to the existing evidence base by comparing the direct- and indirect-effect estimates for the locational factors that affect FDI inflows. We have found that the direct- and indirect-effect estimates for each locational factor have the same sign, but the indirect-effect estimates are always smaller than (about 12\% - 20\% of) the direct-effect estimates. Given that the signs of the direct- and indirect-effect estimates are the same, our findings indicate that province-specific factors have spill-over effects on FDI in neighboring provinces. Stated differently, neighboring provinces are able to attract higher levels of FDI when the levels of per-capita GDP, domestic investment, openness to trade, secondary-school enrollment and governance quality in one of the provinces increases. However, the spill-over effect disappears as the distance between the province and its neighbors increases.

Fourth, we have also added to the existing evidence base by estimating the level of spatial dependence in the distribution of registered FDI capital across Vietnamese provinces. The effect of spatial dependence is positive and remains robust to change in the specification of the weight matrix from one nearest neighbor and 3 nearest neighbors to distance cut-off values of $186 \mathrm{~km}$ and $350 \mathrm{~km}$. This finding indicates that the distribution of registered FDI between Vietnamese provinces is subject to agglomeration dynamics. Indeed, a $10 \%$ increase in distance-weighted value of the FDI in neighboring provinces tends to increase the FDI in a province by $1.2 \%-1.8 \%$. This agglomeration effect explains the concentration of FDI within three clusters in the North, the Middle and South of the Country. 
However, we have also established that the spatial-dependence effect tends to increase as the distance between a given province and its neighbors increases. Indeed, the spatial lag coefficient increases from 0.116 for one nearest neighbors to 0.183 when the distance is set at $350 \mathrm{kms}$ between one province and its furthest neighbor. This finding indicates that the agglomeration effect is not limited to the nearest neighbors of an FDI-intensive province. If anything, the agglomeration effect is spread over a larger geographical space; and neighbors at the periphery are more likely to benefit from FDI inflows into an FDI-intensive province.

Three policy implications follow from our findings. First, FDI inflows into Vietnamese provinces are highly sensitive to labor costs. Nevertheless, we do not recommend wage moderation as a province-level policy aimed at attracting FDI. As indicated in section 3 above, provincial clusters with the highest levels of FDI are those with the highest levels of per-capita GDP too. Hence, provinces within such clusters would be better-placed to afford wage moderation compared to provinces within clusters of low per-capita GDP and FDI concentration levels. Therefore, wage moderation as a means of attracting FDI is likely to have the adverse consequence of perpetuating inter-province disparity in terms of both FDI concentration and per-capita GDP levels.

The second policy implication that follows from our findings relates to the role of education. We found that the rate of secondary school enrolment has the largest direct-effect on FDI inflows. Approximately, a $1 \%$ increase in the rate of secondary education enrolment is associated with $2 \%$ increase in registered FDI. In addition, our findings indicate secondary school enrolment has high levels of spill-over effects on FDI in neighboring provinces and the existing literature indicates that the personal returns on education are positive in Vietnam (see, for example, Gallup, 2002; Liu, 2006 and Pham and Reilly, 2007). Therefore, there is evidential case for increasing investment in education as a means of both attracting FDI into provinces and reducing income disparities between provinces. 
The third policy implications of our findings relate to governance quality, as measured by the provincial competitiveness index (PCI). As indicated above, PCI measures the province-level perceptions of the quality of economic governance institutions and business environment. It consists of nine sub-indexes: entry costs; land access and security of tenure; transparency and access to information; time costs of business start-ups; proactivity or local administration; informal charges; quality of business support services; labor training services; and legal institutions. Our findings indicate that the direct effect of PCI is positive but small (usually, around 0.03 ). In addition, the PCI in one province has no spill-over effects on FDI inflows into neighboring provinces. This finding indicates that inter-province competition based on PCI is the least effective strategy compared to other policy options that involve increasing education levels, domestic investment or openness to trade.

\section{References}

Abreu, Maria; Henri L.F. de Groot; and Raymond J.G.M. Florax. 2004. Space and Growth: A Survey of Empirical Evidence and Methods. Working Paper No.TI 04-129/3. Amsterdam:Tinbergen Institute

Anselin, Luc. 1988. Spatial Econometrics, Methods and Models. Dordrecht: Kluwer Academic Publishers.

Anselin, Luc; Anil K. Bera; Raymond J.G.M. Florax; and Mann J. Yoon. 1996. Simple Diagnostic Tests for Spatial Dependence. Regional Science and Urban Economics 26, no. 1, pp. $77-104$.

Anselin, Luc, and Anil K. Bera. 1998. Spatial Dependence in Linear Regression Models with an Introduction to Spatial Econometrics, In Handbook of Applied Economic Statistics, ed. Aman Ullah and David E. Giles. Berlin: Springer. 
Baltagi, Badi H.; Peter Egger; and Michael Pfaffermayr M. 2007. Estimating Models of Complex FDI: Are there Third-Country Effects? Journal of Econometrics 140, no.1, pp. 26081.

Baum, Christopher F. 2006. An Introduction to Modern Econometrics Using Stata. Texas: Stata Press.

Blonigen, Bruce A.; Ronald B. Davies; Glen R. Waddell; and Helen T. Naughton. 2007. FDI in Space: Spatial Autoregressive Relationships in Foreign Direct Investment. European Economic Review 51, no. 5, pp. 1303-25.

Cole, Matthew A.; Robert J. R. Elliott; and Jing Zhang. 2009. Corruption, Governance and FDI Location in China: A Province-Level Analysis. Journal of Development Studies 45, no. 9, pp. $1494-512$.

Coughlin, Cletus C., and Eran Segev. 2000. Foreign Direct Investment in China: A Spatial Econometric Study. The World Economy 23, no.1, pp. 1-23.

Du, Julian; Yi Lu; and Zhigang Tao. 2008. Economic Institutions and FDI Location Choice: Evidence from US Multinationals in China. Journal of Comparative Economics 36, no. 3, pp. $412-29$.

Elhorst, Paul J. 2010a. Matlab Software for Spatial Panels (paper presented at the IVth World Conference of the Spatial Econometrics Association (SEA), Chicago, June 9-12, 2010).

Elhorst, Paul J. 2010b. Applied Spatial Econometrics: Raising the Bar. Spatial Economic Analysis 5, no.1, pp. 9-28.

Gallup, John L. 2002. The wage, labor market and inequality in Viet Nam in the 1990s. World Bank Policy Research Working Papers, no. 2896.

Gamboa O.R.E. (2013) Foreign direct investment determinants and spatial spillovers across Mexico's states. The Journal of International Trade and Economic Development: An International and Comparative Review 22, no. 7, pp. 993-1012 
General Statistics Office of Vietnam. 2011. Statistical Data Online, 2011. Hanoi: General Statistics Office. http://www.gso.gov.vn (accessed November 15, 2011).

Head, Keith, and Thierry Mayer. 2004. Market Potential and the Location of Japanese Investment in the European Union. Review of Economics and Statistics 86, no. 4, pp. 959-72. Head, Keith; John Ries; and Deborah Swenson. 1995. Agglomeration Benefits and Location Choice: Evidence from Japanese Manufacturing Investments in the United States. Journal of International Economics 38, no. 3-4, pp. 223-47.

Karim, Noor Al-Huda Abdul and Euan Fleming. 2012. Factors Affecting Foreign Direct Investment in Malaysia's Manufacturing Sector: An Analysis across States. The Singapore Economic Review 57, (04) 1250015 available from: http://dx.doi.org/10.1142/S0217590812500154 Accessed 9 December 2013.

Ledyaeva, Svetlana. 2009. Spatial Economic Analysis of Foreign Direct Investment Determinants in Russian Regions. The World Economy 32, no. 4, pp. 643-66.

LeSage, James, and Robert K. Pace. 2009. Introduction to Spatial Econometrics. Boca Raton: CRC Press Taylor \& Francis Group.

Liu, A.Y.C. 2006. Changing wage structure and education in Vietnam 1993-1998: the roles of demand. Economics of Transition 14, no.4, pp.681-706.

Malesky, Edmund. 2007. Provincial Governance and Foreign Direct Investment in Vietnam', in Twenty Years of Foreign Direct Investment in Vietnam. HCMC: Knowledge Publishing House.

Moran, Patrick A. P. 1950. Notes on Continuous Stochastic Phenomena. Biometrika 37, no. 1-2, pp. 17-23.

Na, Lv, and William S. Lightfoot. 2006. Determinants of Foreign Direct Investment at the Regional Level in China. Journal of Technology Management in China 1, no.3, pp. 262-78. 
Nguyen, Phi L. 2006. Foreign Direct Investment and its Linkage to Economic Growth in Vietnam: A Provincial Level Analysis. Adelaide, SA 5001, Australia.

Pham, Hoang M. 2002. Regional Economic Development and Foreign Direct Investment Flows in Vietnam: 1988-98. Journal of the Asia Pacific Economy 7, no. 2, pp. 182-202.

Pham, H., and Reilly, B. 2007. The gender pay gap in Vietnam, 1993-2002: a quintile regression approach. Journal of Asian Economics 185, no.5,pp. 775-806.

Pham, Thu H. 2008. The Effects of ODA in Infrastructure on FDI Inflows in Provinces of Vietnam: 2002-2004. Working Paper No.089. Hanoi: Vietnam Development Forum.

Vietnamese Chamber of Commerce and Industry (VCCI) and the U.S. Agency for International Development-supported Vietnam Competitiveness Initiative (USAID/VNCI). Provincial Competitiveness Index. 2011. Hanoi: VCCI http://www.pcivietnam.org/index.php?lang=en (accessed October 25, 2011).

Seldadyo, Harry; Paul J. Elhorst; and Jakob de Haan. 2010. Geography and Governance: Does Space Matter? Papers in Regional Science 89, no.3, pp. 625-40.

Toshiyuki, Matsuura; Kiyoyasu Tanaka; and Shujiro Urata. 2010. The Determinants of Offshore Production by Multinational Corporations (MNCs): A Comparison of Japanese and US MNCs. Working Paper No. 234: Chiba: Institute of Developing Economies

UNCTAD. 2011. UNCTAD FDI Database, 2011. Geneva: UNCTAD http://unctadstat.unctad.org (accessed October 30, 2011).

Urata, Shujiro, and Hiroki Kawai. 2000. The Determinants of the Location of Foreign Direct Investment by Japanese Small and Medium-sized Enterprises. Small Business Economics 15, no. 2, pp. 79-103.

Villaverde, José, and Adolfo Maza. 2011. Foreign Direct Investment in Spain: Regional Distribution and Determinants. International Business Review 21, no. 4, pp. 722-733. 
Vu, Thanh T.A.; Viet T. Le; and Tat T. Vo. 2007. Provincial Extralegal Investment Incentives in the Context of Decentralization in Viet Nam: Mutually Beneficial or a Race to the Bottom?', United Nations Development Programme (UNDP) Discussion Paper, Hanoi: UNDP http://www.undp.org.vn/digitalAssets/9/9716_071205_provincentives.pdf (accessed October, October 25, 2011). 


\section{Appendices}

\section{A1: List of Provinces in the Sample}

\begin{tabular}{|c|c|}
\hline REGIONS & PROVINCES \\
\hline Central Highlands & Dak Lak, Lam Dong, Dak Nong, Gia Lai, Kon Tum \\
\hline Mekong River Delta & $\begin{array}{l}\text { An Giang, Hau Giang, Thai Binh, Vinh Long, Soc Trang, } \\
\text { Ca Mau, Long An, Can Tho, Kien Giang, Tra Vinh, Ben } \\
\text { Tre, Dong Thap, Tien Giang }\end{array}$ \\
\hline North Central and Central Coastal area & $\begin{array}{l}\text { TT-Hue, Khanh Hoa, Quang Binh, Quang Nam, Nghe } \\
\text { An, Ninh Thuan, Da Nang, Binh Dinh, Phu Yen, Quang } \\
\text { Ngai, Ha Tinh, Quang Tri, Thanh Hoa, Binh Thuan }\end{array}$ \\
\hline Northern midlands and mountain areas & $\begin{array}{l}\text { Lai Chau, Thai Nguyen, Dien Bien, Lang Son, Cao } \\
\text { Bang, Bac Kan, Ha Giang, Lao Cai, Yen Bai, Son La, } \\
\text { Hoa Binh, Tuyen Quang, Phu Tho, Bac Giang }\end{array}$ \\
\hline Red River & $\begin{array}{l}\text { Hung Yen, Quang Ninh, Ha Nam, Nam Dinh, Hai } \\
\text { Duong, Ninh Binh, Hai Phong, Bac Ninh, Ha Noi, } \\
\text { Vinh Phuc }\end{array}$ \\
\hline South East & $\begin{array}{l}\text { Dong Nai, Binh Duong, Binh Phuoc, BRVT, Tay Ninh, } \\
\text { HCMC }\end{array}$ \\
\hline
\end{tabular}

\section{A2: Moran s I Test for Spatial Autocorrelation InFDI}

\begin{tabular}{lcccc}
\hline \hline Moran s I test & W1 & W3 & W186 & W350 \\
\hline \multirow{2}{*}{$\operatorname{lnFDI} 2006$} & 0.426 & 0.290 & 0.181 & 0.141 \\
& $(0.00)$ & $(0.00)$ & $(0.00)$ & $(0.00)$ \\
lnFDI 2007 & 0.449 & 0.317 & 0.203 & 0.161 \\
& $(0.00)$ & $(0.00)$ & $(0.00)$ & $(0.00)$ \\
lnFDI 2008 & 0.419 & 0.312 & 0.204 & 0.163 \\
& $(0.02)$ & $(0.00)$ & $(0.00)$ & $(0.00)$ \\
lnFDI 2009 & 0.438 & 0.325 & 0.221 & 0.178 \\
& $(0.00)$ & $(0.00)$ & $(0.00)$ & $(0.00)$ \\
\hline
\end{tabular}

Notes: Two-sided and under normality. P-values are in parenthesis. 
A3: Data sources

\begin{tabular}{|c|c|c|}
\hline$\overline{\text { Data }}$ & $\begin{array}{l}\text { Unit of } \\
\text { Measurement }\end{array}$ & Source \\
\hline $\begin{array}{l}\text { Foreign direct } \\
\text { investment }\end{array}$ & US\$ & $\begin{array}{l}\text { Provided by General Statistics Office of Vietnam } \\
\text { (GSO) }\end{array}$ \\
\hline $\begin{array}{l}\text { Exchange rate } \\
\text { (Market rate) }\end{array}$ & $\begin{array}{l}\text { US Dollars per } \\
\text { Vietnamese Dong }\end{array}$ & $\begin{array}{l}\text { International Monetary Fund, International Financial } \\
\text { Statistics Annual Series }\end{array}$ \\
\hline Population & People & Provided by GSO \\
\hline GDP & Vietnamese Dong & Provided by GSO \\
\hline Labor cost & Vietnamese Dong & $\begin{array}{l}\text { Principle indicators of enterprises } \\
\text { by regions and provinces, GSO }\end{array}$ \\
\hline $\begin{array}{l}\text { Domestic } \\
\text { investment }\end{array}$ & Vietnamese Dong & Provided by GSO \\
\hline $\begin{array}{l}\text { Exports and } \\
\text { Imports }\end{array}$ & US\$ & Provided by GSO \\
\hline $\begin{array}{l}\text { Provincial } \\
\text { Competitivene } \\
\text { ss Index }\end{array}$ & Index & http://www.pcivietnam.org/index.php?lang=en \\
\hline $\begin{array}{l}\text { Lower- } \\
\text { secondary } \\
\text { school } \\
\text { enrolment }\end{array}$ & Number of pupils & Provided by GSO \\
\hline
\end{tabular}


A4: Summary statistics

\begin{tabular}{|c|c|c|c|c|c|c|}
\hline Variable & Description & Observation & Mean & Std. Dev. & Min & Max \\
\hline FDI & $\begin{array}{l}\text { Foreign direct } \\
\text { investment } \\
\text { /population in } \\
2005 \text { Vietnamese } \\
\text { Dong (VND) }\end{array}$ & 248 & 19464991 & 39326062 & 2302 & 292598592 \\
\hline PCGDP & $\begin{array}{l}\text { Gross domestic } \\
\text { investment } \\
\text { /population in } \\
2005 \text { VND }\end{array}$ & 248 & 11176855 & 13709054 & 3274478 & 124828848 \\
\hline $\mathrm{LC}$ & $\begin{array}{l}\text { Labour cost per } \\
\text { employee per } \\
\text { month in } 2005 \\
\quad \text { VND }\end{array}$ & 248 & 1546279 & 486483.8 & 749538.6 & 3801693 \\
\hline DI & $\begin{array}{l}\text { Domestic } \\
\text { investment } \\
\text { /population in } \\
2005 \mathrm{VND}\end{array}$ & 248 & 4318213 & 2638279 & 566728 & 20591074 \\
\hline OP & $\begin{array}{l}\text { Openness: } \\
\text { Exports plus } \\
\text { imports/GDP }\end{array}$ & 248 & 69.594 & 106.3745 & 0.933 & 749.690 \\
\hline PCI & $\begin{array}{l}\text { Quality of } \\
\text { economic } \\
\text { governance } \\
\text { institutions and } \\
\text { business } \\
\text { environment }\end{array}$ & 248 & 55.388 & 7.862 & 36.390 & 77.2 \\
\hline LS & $\begin{array}{l}\text { Number of pupils } \\
\text { in lower } \\
\text { secondary } \\
\text { school/population } \\
\text { in } 1000 \text { s }\end{array}$ & 248 & 69.598 & 13.241 & 34.135 & 105.387 \\
\hline $\mathrm{W}^{*} \mathrm{FDI}$ & $\begin{array}{l}\text { Spatially-lagged } \\
\text { FDI }\end{array}$ & 248 & 25243789 & 44287970 & 2302 & 292598048 \\
\hline
\end{tabular}


Tables

Table 1 Summary of empirical findings on FDI with respect to spatial dependence between sub-national regions

\begin{tabular}{|c|c|c|c|}
\hline Studies & $\begin{array}{l}\text { Sub-national } \\
\text { regions }\end{array}$ & $\begin{array}{l}\text { Sign of } \\
\text { spatial lag }\end{array}$ & $\begin{array}{l}\text { Motive } \\
\text { for FDI }\end{array}$ \\
\hline Ledyaeva(2009) & $\begin{array}{l}\text { Russian } \\
\text { regions }\end{array}$ & $(-)$ & Vertical \\
\hline $\begin{array}{l}\text { Villaverde and } \\
\text { Maza (2012) }\end{array}$ & $\begin{array}{l}\text { Spanish } \\
\text { regions }\end{array}$ & (insignificant) & $\begin{array}{l}\text { Export } \\
\text { platform }\end{array}$ \\
\hline Gamboa (2013) & $\begin{array}{l}\text { Mexican } \\
\text { states }\end{array}$ & $(+)$ & $\begin{array}{l}\text { Complex } \\
\text { vertical }\end{array}$ \\
\hline
\end{tabular}

Table 2 Sectoral composition of registered FDI in 2009

\begin{tabular}{lr}
\hline \hline & \multicolumn{2}{c}{ Sector share in total registered } \\
Sectors & FDI (\%) \\
\hline \hline Agriculture, forestry and fishing & 1.75 \\
Mining and quarrying & 1.68 \\
Manufacturing & 51.05 \\
Electricity, gas, stream and air conditioning supply & \\
Water supply, sewerage, waste management and & 1.10 \\
remediation activities & \\
Construction & 0.03 \\
Wholesale and retail trade; Repair of motor vehicles & 5.59 \\
and motorcycles & \\
Transportation and storage & 0.68 \\
Accommodation and food service activities & 1.32 \\
Information and communication & 6.34 \\
Financial, banking and insurance activities & 2.70 \\
Real estate activities & 0.72 \\
Professional, scientific and technical activities & 23.59 \\
Administrative and support service activities & 0.36 \\
Education and training & 0.10 \\
Human health and social work activities & 0.15 \\
Arts, entertainment and recreation & 0.51 \\
Other activities & 1.96 \\
\hline \hline
\end{tabular}

Source: Own calculation based on data from the General Statistics Office (GSO) of Vietnam 
Table 3 Top-ten Vietnamese provinces with registered FDI in 2009 (millions of US\$)

\begin{tabular}{llcc}
\hline Region & Province & $\begin{array}{c}\text { Registered } \\
\text { FDI }\end{array}$ & $\begin{array}{c}\text { Share in } \\
\text { Total FDI }\end{array}$ \\
\hline South East & HCMC & 30981.6 & $18 \%$ \\
South East & BRVT & 25700.2 & $15 \%$ \\
Red River & Ha Noi & 22306.9 & $13 \%$ \\
South East & Dong Nai & 17838.1 & $10 \%$ \\
South East & Binh Duong & 13924.6 & $8 \%$ \\
North Central and Central Coastal & Ninh Thuan & 10055.9 & $6 \%$ \\
North Central and Central Coastal & Ha Tinh & 8068.5 & $5 \%$ \\
North Central and Central Coastal & Phu Yen & 8060.8 & $5 \%$ \\
North Central and Central Coastal & Thanh Hoa & 7040.3 & $4 \%$ \\
North Central and Central Coastal & Quang Nam & 5190.5 & $3 \%$ \\
\hline Total & & $\mathbf{1 4 9 1 6 7}$ & $\mathbf{8 5 \%}$ \\
\hline \hline
\end{tabular}

Source: Own calculation based on data from the General Statistics Office (GSO) of Vietnam 
Table 4 Determinants of FDI with different weight matrices for spatial dependence

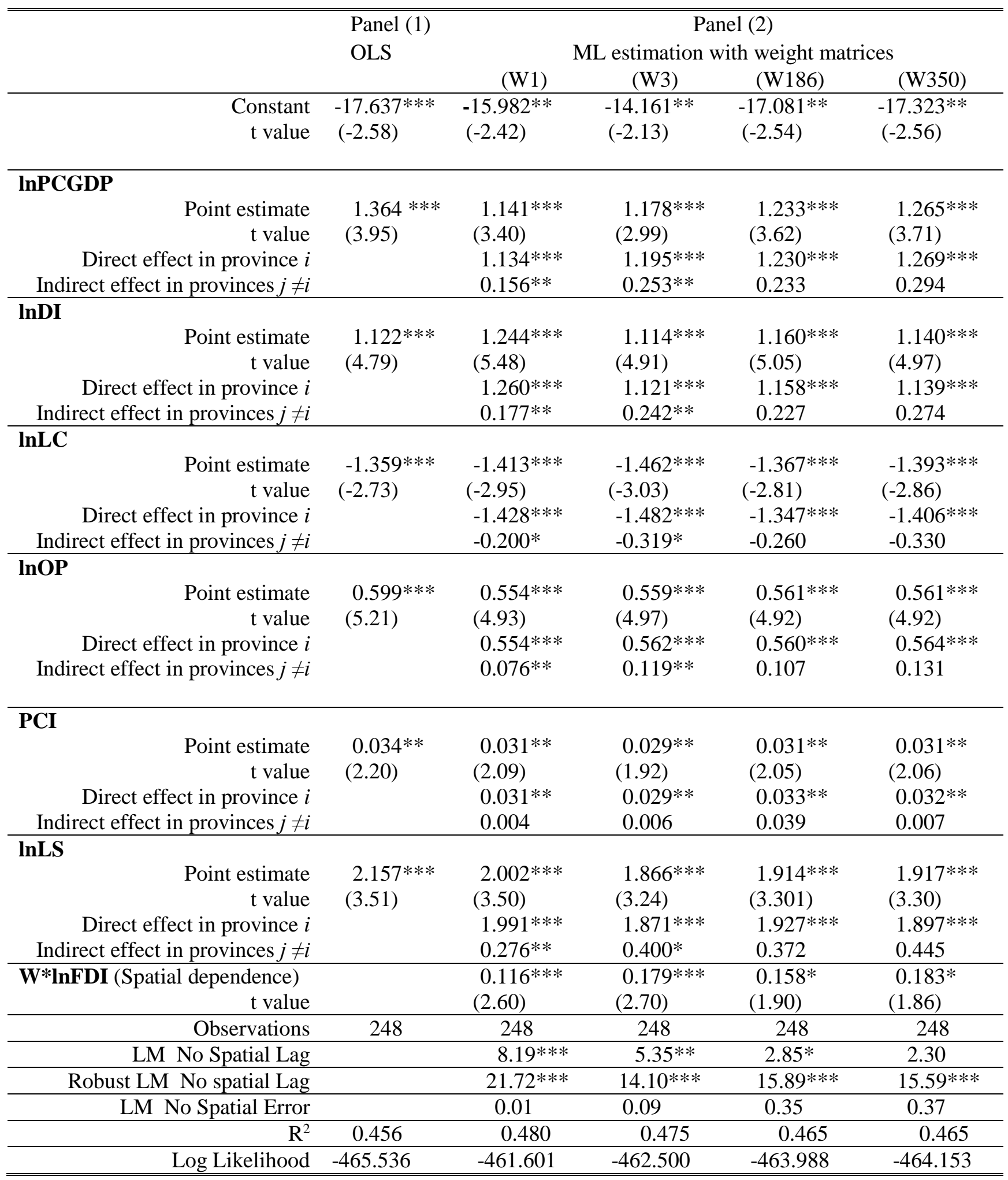

Note: $\mathrm{t}$ values are in parenthesis. $* * *, * *, *$ denotes $0.01,0.05,0.10$ significance level respectively. 


\section{Figures}

Figure 1 Provincial distribution of cumulative FDI in Vietnam in 2009 (million of US\$)

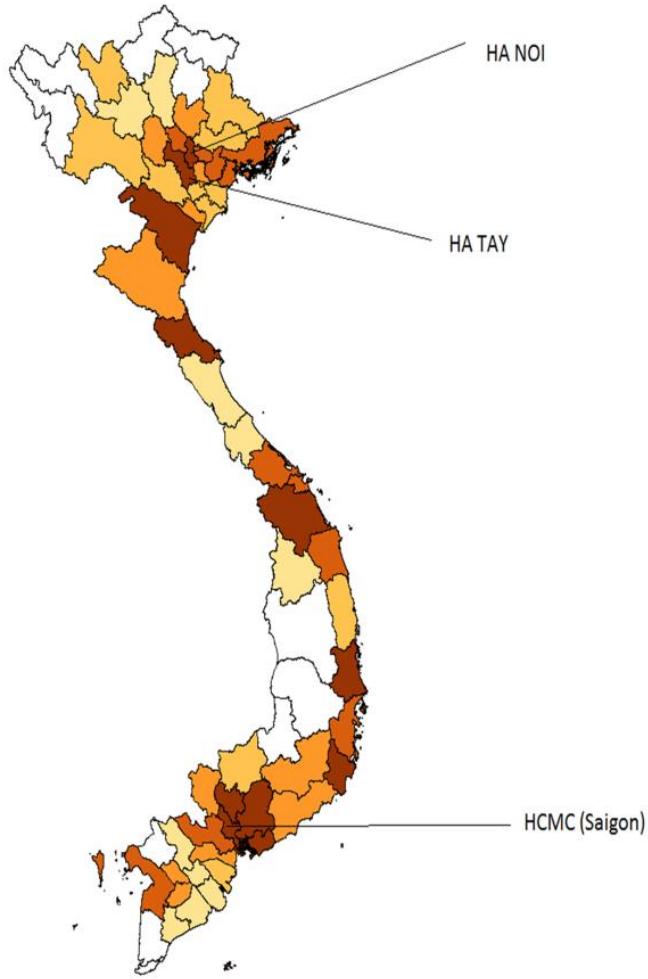

Quantile: FDI

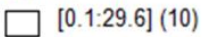

$\square[42.2: 95.7](10)$

$[113.7: 341.7](11)$

$[347.4: 1341](11)$

[1345:4828] (11)

$[5191: 7.047 \mathrm{e}+004](11)$

Ha Noi and Ha Tay merged in 2007. Therefore, the cumulative FDI for Ha Noi in 2009 is equally allocated to both provinces in this figure. 